\title{
Impact of Information Technology on Organizations: The State of the Art
}

\author{
A. B. J. M. WIJNHOVEN AND D. A. WASSENAAR
}

Drs A. B. J, M. Wijnhoven and Drs D. A. Wassenaar are with the University of Twente, School of Management studies, PO Box 217, 7500 AE Enschede, The Netherlands.

Drs Wijnhoven received his M.A. degree in political science research methodology at the University of Nijmegen (Netherlands). He then became an assistant professor in organization science with the Faculty of Public Administration, University of Twente. He is now leader of a programme on impact research.

Drs Wassenaar, who studied economics, has worked in the field of electronic data processing as information analyst, project manager, information management consultant and manager of an information consultancy department. He is now leading a project on information management and planning research.

We would like to thank Professor Mike Ryan (Michigan Business School) and Drs Ko de Ruyter (University of Twente) for their useful suggestions in writing English.

LAND F. (1982). Adapting to changing user requirements. Information and Management, 5, pp. 59-75.

${ }^{2}$ Gat.BRaith, J. R. (1973). Designing complex organizations. Reading, Mass: Addison-Wesley. TUSHMAN, M. L. AND NADLER, D. A. (1978). Information processing as an integrating concept in organizational design. Academy of Management

\section{Why study impacts?}

A lot of prescriptive scientific work has been done on systems development. However, we lack systematic knowledge on the behavioral and empirical aspects of this science. Also systematic evaluation of present systems is absent. Impact research is intended to give system development its necessary feedback and presents opportunities for learning. The concept of evolutionary design ${ }^{1}$ is appropriate in this respect.

Some issues which are central to impact research are mentioned below:

1. 'How to fit information technology in an effective way within the organization?' It is important to anticipate the necessary organizational changes for effective system implementation. Sometimes a certain system cannot work within its organizational environment; then we will have to change the system, the organization, or both. ${ }^{2}$

2. 'What will be the position of new people coming into the organization?' Will they change the organization structure and culture? A new way of personnel management might probably be needed. ${ }^{3}$

3. What will happen to the people who were already in the organization before automation? Will they have better jobs, higher salaries, more satisfaction? Are some people becoming redundant? ${ }^{4}$

4. 'Are the systems reaching their potential?' Are they meeting the objectives of changing the organization in more efficient, effective and competitive ways? Are they changing the way in which the organization is managed? Is the organization better fitted to its environment? ${ }^{5}$

5. On a macro level the questions are: What will be the effects of 
Review, July, pp. 613-624. MARKLS, M. I. (1984). Systems in organizations: Bugs and features. Marshfield Mass: Pitman Publishing.

MIIILRAUFF, R, J, AND RI:YNOLISS, (i. W. (1982). Effective information systems management. Columbus: (. 1. Mt:Rrill..

HERN, H AND SCHUIMANN, M. (1984): Das Ende der Arbeitsleitung? Rationalivierang in der industriellen Produktion. Munich: Beck.

s(H11.). 3. (1987). Information technology, organization. and the response to strategic challenges. California Management Review, fall, pp. 33-50.

"I.FONTHE, w. (1986). The future impact of automation on workers. Oxford: Oxford University Press.

TKRAIMIR, K. 1. AND KING, J, 1 . (1987). Computers and the constitution: A helpful, harmful or harmless relationship. Public administration review, pp. 93-105.

${ }^{x}$ CF (Huld, op. cit, Rel. 5 .

"MASON, R. O. AND MITROHI. 1. 1. (197.3). A program for research on management information systems. In: Management Scionce. Theory, 19, pp, 475-487.

"MARkUS, op. cit., Ref., 2, p. 68.

"Ibid. information technology implementation in organizations on:

(a) Employment."

(b) The education needed.

(c) The structure of our economy.

(d) The position of the national economy on a global scale.

(e) Changes in the political system. ${ }^{7}$

(f) The relation between consumer and producer? (More on-orderproduction? Selling and buying by computer?).

(g) What will be the form of business in the future? Will there only be place for very big firms, or are there new opportunities for small business?

(h) What kind of psychological orientation will best be suited for working in modern organizations? Are there more possibilities for disabled people? Will we get a new kind of disablement?"

\section{Theoretical perspective on studying impacts of information technology in organizations}

Following Markus ${ }^{10}$ we propose that impacts occur: '. . when system design features interact with specific organizational features'. However, when system features and their organizational context are strongly different, a conflict is highly probable when system and organization are not willing to change in order to decrease the dissonance between them. This conflict is, of course, the result of the system development process. With respect to this, the relationship between users and designers is of great importance.

Often there is an important difference between designers' intentions and users' practice. Examples that frequently occur are partial use, unintended use, abusive use, fraud, crime, resistance and sabotage. Designers generally blame these kinds of behavior on user characteristics; however, very often it is the result of their own design and intentions. ${ }^{11}$

To understand more completely what is at stake here, we must analyse the designer-user interaction. In these interactions, power is a crucial phenomenon, because information is a central asset for power. It is clear, then, that information systems are able to change existing power balances in the organization. This power change, and therefore also the information system. will often be resisted by the (relative) power losers.

The impacts of an information system have also to be regarded in an organizational context (Figure 1).

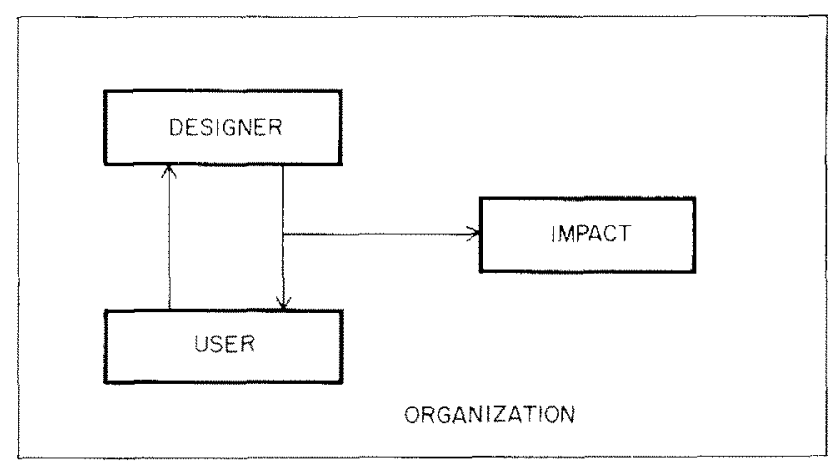

Figure 1. Interaction theory in scheme 
Because it is necessary to see impacts in their organizational context, we think it is necessary to reconsider the concept of organization. We then hope to obtain a more systematic view of the crucial variables being affected by information technology.

As a start for our definition, we return to Barnard, ${ }^{12}$ who defined cooperative systems as: '. . a complex of physical, biological, personal and social components which are in a specific systematic relationship by reason of the cooperation of two or more persons for at least one definite end.'

Of course cooperative systems have to be organized. Ciborra states that two variables are crucial to organization of the cooperative system..$^{13}$ One variable is uncertainty, as Galbraith ${ }^{14}$ has already pointed out. The other variable is the extent to which organization members share each others' goals, goal congruence. From these variables a crucial typology of organizations follows (Figure 2).

Ciborra argues that in a market way of organizing there is no need for strong goal congruence, and that products are quite simple so that there is low uncertainty with respect to quality, quantity, etc. Here the invisible hand will suffice as a coordinating mechanism. On the other hand, the firm mostly needs some kind of visible hand, which is often called bureaucracy. In this way complex transactions in the cooperative system are managed, and interdepartmental conflicts are resolved. Sometimes goal congruence is very strong, but there is much uncertainty

${ }^{12}$ BARNARD, C. 1. (1938). The function of the executive. Cambridge, Mass: Harvard University Press. (15th print 1962.)

${ }^{13}$ CIBORRA, C. U. (1987). Research agenda for a transaction costs approach to information systems. In: Critical issues in information systems research ( $\mathrm{R}$. J. BOLAND AND R. A. HIRSCHHEIM, eds), pp. 253-274. Chichester: Wiley.

${ }^{14}$ Galbraith, op. cit, Ref. 2.

${ }^{15}$ OUCHI, w. G. (1980). Markets, bureaucracies, and clans. Administrative Science Quarterly, 25, pp. 129-141.

${ }^{16}$ BOISOT, м.(1987). Information and organizations, the manager as anthropologist. London: Fontana.

${ }^{17}$ MinTZBERG, H. (1983). Structures in fives: Designing effective organizations. Englewood Cliffs, NJ: Prentice-Hall

${ }^{18}$ Borsot M. H. (1986). Markets and hierarchies in a cultural perspective. Organiza. tion studies, 7, pp. 135-158.

${ }^{19}$ Ibid. with respect to services and products. Coordination is achieved by use of informal relationships. Ouchi then talks about invisible handshaking. ${ }^{15}$ Examples of this kind of coordination are clans.

Correspondence between the concept of organization and information technology can be clearly shown by use of the variables information codification and diffusion. Using these variables Boisot constructs a communication-space in which four types of organizations can be placed (Figure 3). ${ }^{16}$

Interestingly enough Mintzberg's famous typology of organizations ${ }^{17}$ can be perfectly fitted in Boisot's $c$-space ${ }^{18}$ as shown in Figure 4 . This scheme of organizations shows only one medal of the coin of cooperative systems: internal organization. The external relations of organizations, which also belong to the cooperative system need an extension on the c-space. Boisot has developed a scheme for analysing extemal relations (Figure 5). ${ }^{19}$

The dotted line marks the break-even point for internal versus external transactions for the organization in the cooperative system. The codification diffusion variables can also be applied to the internal/

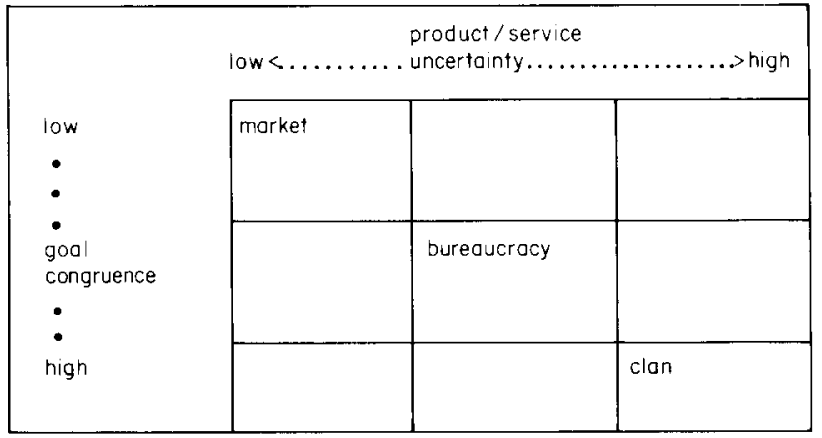

Figure 2. Three organizational forms (Ref. 13, p. 260) 
${ }^{20}$ Op. cit., Ref. 5.

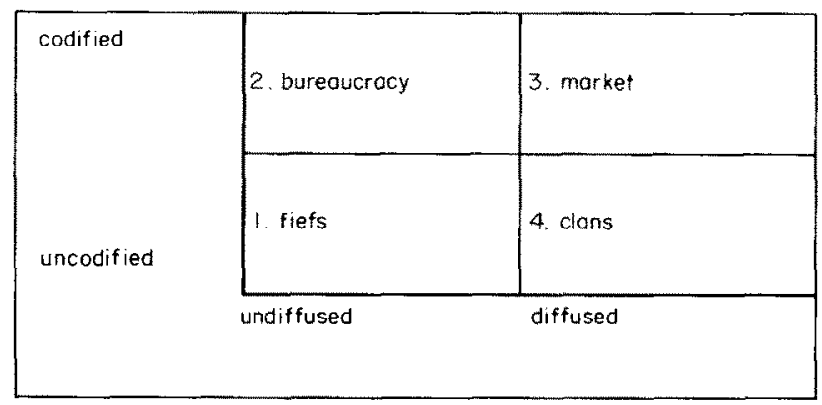

Figure 3. (Boisot's c-space Ref. 16, Fig. 5.1, p. 100.)

external transaction field. John Child has applied this analysis to six types of organization/cooperative systems (Figure 6). ${ }^{20}$

Organization types can be related as following with an information technology:

1. Integrated hierarchy. In this type there is a personalized form of centralized and strongly hierarchical coordination and control. Management systems are often of a non-formalized kind.

2. Semi-hierarchical mode. Examples of this type are the multidivisionalized firm, the holding company and the parent-subsidiary configuration. Separate divisions are quite autonomous, and they only are coordinated in regard to financial affairs, especially their rate of return on investments. We can then speak of a quasi-market coordination.

3. Co-contracting mode. In this type the cooperative system is organized as a "mutual organization" formed by a set of independent co-contractors engaging in a recurring relationship, in which the parties are both principals and agents'. That is different firms are working together for a general purpose.

4. Coordinated contracting mode, or quasi-firm. It ". . relates a prime contract or producer as principal with a set of subcontractors as agents in a recurring relationship which may persist over many years'. Also this type of organization is far from a market type, and

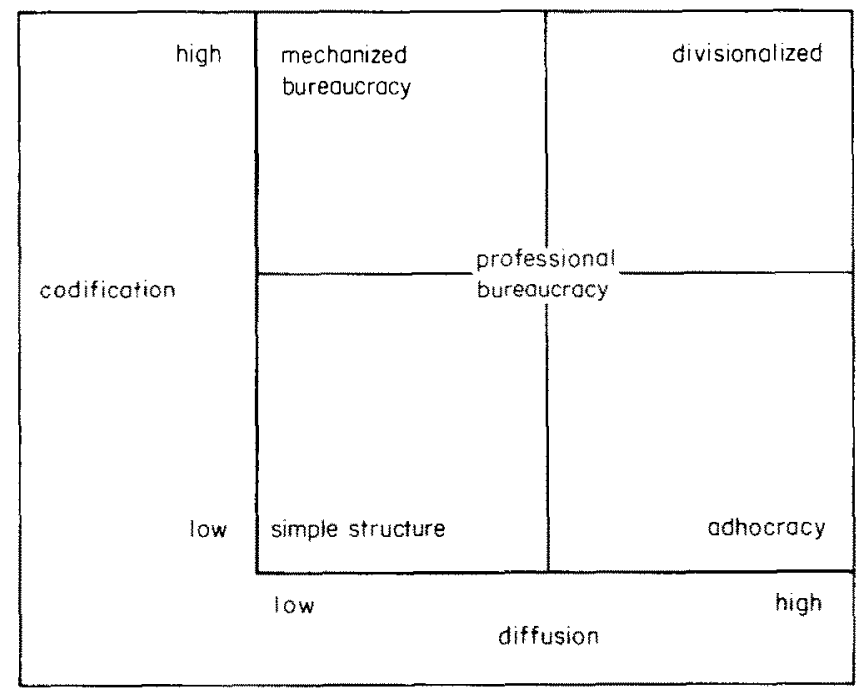

Figure 4. Mintzberg's typology of organizations 


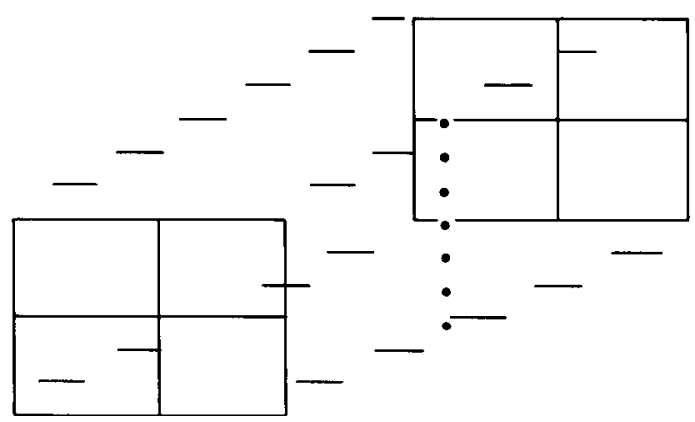

Figure 5. Boisot's scheme for external relations analysis (Ref. 18)

seems to be more clan-like; however, there is a hierarchy, and of course different firms can compete for one subcontract in the future.

5. Coordinated revenue links. This refers primarily to licensing and franchising. This type of organization is strongly of a market type. Diverse organizations can strive for a licence to produce a type of product; they are completely autonomous firms; however, the franchise operator wants to control quality and its good name.

6. The spot network. This type of 'organization' consists of nonrecurring contracts between independent firms.

To conclude this part about the concept of organization we want to stress two important notions:

1. The kind of information technology and type of organization are closely related.

2. The boundaries of the cooperative system are often difficult to define, so a separation between organizational internal and external communication is quite arbitrary.

\section{A short survey of approaches}

Two points have to be considered here: the nature of impact itself; research designs with respect to impact.

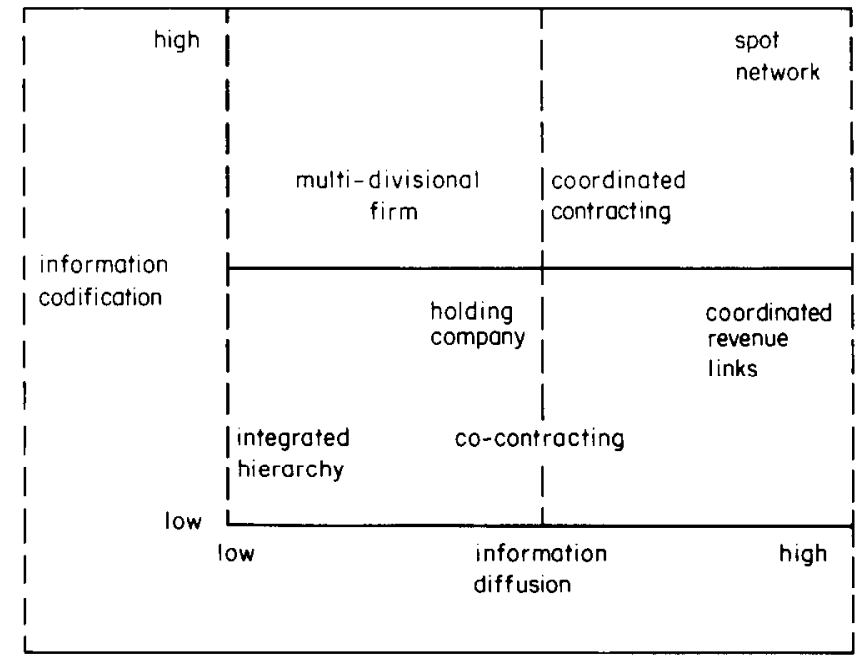

Figure 6. Information peocessing requirement of organizing modes (Ref. 5, Fig. 2, p. 45) 
${ }^{21}$ LEEGE, D. C. AND FRANCIS, w. L. (1974). Political research, design, measurement and analysis. New York: Basic Books.

${ }^{22}$ KUBICEK, H. (1979). Informationstechnologie und Organisationsforschung: Eine kritische Bestandsaufname der Forschungsergebnisse. Mensch und Computer, Zur Kontroverse über ... die ökonomische und gesellschaftliche Auswirkungen der EDV ( $\mathrm{H}$. R. HANSEN, K. T? SCHRÖDER AND H. J. WEHHE, eds), pp. 5379. Munich. markus, op. cit. Ref. 2.

${ }^{23}$ MARKuS, op. cit., Ref. 2, especially chapter 8.

${ }^{24}$ GLASER, B. G. AND STRAUSS, A. L. (1967/ 1979). The discovery of grounded theory, strategies for qualitaive research. Chicago: Aldine Publishing Company. Galtung, 1. (1967). The social sciences, an essay on polarization and integration. PRIO publication No. M-3. Oslo: International Peace Research Institute.

${ }^{25}$ FRANZ, C R. AND ROBFY, D. (1987). Strategies for research on information systems in organizations. A critical analysis of research purpose and time frame. In: $\mathrm{Cr}$ tical issues in information systems research. (R. J. BOLAND AND R. A. HIRSCHHFIM, eds), pp. 205-227. Chichester: Wiley.

\section{The nature of impact}

The concept of impact seems to suggest one-directional causal thinking. What this kind of reasoning implies will be briefly discussed here. ${ }^{21}$

1. There must be an identifiable set of independent and dependent variables. This is difficult, as the same variables are often dependent as well as independent, e.g. organizational culture has great influence on the type of automation, whereas automation also influences organizational culture.

2. There has to be a time interval between dependent and independent variable. Thus one must measure the same variables at different moments in time, but how does one know the same things are being measured when they are continuously changing?

3. One must identify a correlation between dependent and independent variable, while controlling for the influence of indirect variables and research artifacts. A laboratory experiment has serious external validity problems. Multivariate causal research is only possible with the identification and measurement of all relevant variables, and this is very difficult.

4. Is valid and reliable measurement possible at all?

5. Finally, and most important, the question is whether causal research is really ontologically valid and useful for information policy. With respect to this we mean that causality does not describe social reality at all. Impacts are not simply caused, but created by man in his or her organization and society. ${ }^{22}$ The creation of systems and their impact are the results of implicit or explicit decisions of pcople and their behavior in the organization and society. To neglect this point would be giving information policy an incorrect feedback. Of what use is an analysis without showing how the subject being analysed was realized? The manager, then, will still not know how to influence impacts himself! .3. $^{3}$

\section{Research design}

Two important determinants of research design are purpose and timeframe. ${ }^{24}$ This has been discussed in an interesting way with respect to impact research by Franz and Robey ${ }^{25}$ (see Figure 7).

In studying impacts of information technology we have argued that a multiple time perspective is necessary. Decisions and behaviour have to

\begin{tabular}{|c|c|c|}
\hline & \multicolumn{2}{|c|}{ time frame } \\
\hline & single period & multiple period \\
\hline \multirow{2}{*}{$\begin{array}{l}\text { purpose } \\
\text { testing }\end{array}$} & $\begin{array}{l}\text { observe current stote } \\
\text { (genercte ideos for } \\
\text { factor theories) }\end{array}$ & $\begin{array}{l}\text { observe on-going } \\
\text { processes lgenerate } \\
\text { ideos for process } \\
\text { theories) }\end{array}$ \\
\hline & $\begin{array}{l}\text { test static } \\
\text { associations } \\
\text { (correlational } \\
\text { andysis) }\end{array}$ & $\begin{array}{l}\text { test dynamic } \\
\text { changes (cause and } \\
\text { effect) }\end{array}$ \\
\hline
\end{tabular}

Figure 7. A typology for research strategies for studying MIS (Ref. 25, Table 1, p. 210) 
be observed and included in data about the way impacts occur. When hypotheses about a certain impact of information technology are often supported (well grounded theory ${ }^{26}$ ), there is also the possibility for testing hypotheses instead of discovery as a research aim. The use of testing as a research aim, however, has the danger of thinking in terms of reifications. ${ }^{27}$ If carefully done it can lead to strong generalization, which is, of course, an important aim of science.

Single-period research is not very well suited for generating insights into the nature of impacts. However, we often have no other research method, because of lack of time and money, and organizations (the research units) often do not want researchers to keep employees from their work. Hence, ex post research is a useful design. Some problems are associated with this strategy:

1. There is no direct observation. It is also difficult to achieve multiple-period research.

2. Respondents can easily forget events which are of importance for research. They may also purposely misrepresent reality (cf. rationalization).

3. There can be turnover of organization members. People leave the organization, and so important information is difficult to retrieve.

Doing single-period research simply in the form of multivariate statistical analysis is also a serious possibility if hypotheses are well grounded. However, again the danger of reification is very strong, especially if single-period cross-sectional correlations are interpreted as predictions about what will happen in the future. ${ }^{28}$

\section{Hypotheses}

Some books containing overviews of hypotheses are written by Whisler, ${ }^{29}$ Federico ${ }^{30}$ and Ein-Dor and Segev. ${ }^{31}$ We do not want to summarize thesc books here, but the reader is advised to look at them.

An extremely good overview with respect to hypotheses on especially

${ }^{26}$ GLASER, op. cit., Ref. 24.

${ }^{27}$ BERGER, P. AND LUCKMAN, T. (1967). The social construction of reality: $A$ treatise in the sociology of knowledge. Harmondsworth: Penguin.

${ }^{28}$ HEMPEL, C. G. (Editor) (1965). The funetions of general laws in history. In: Aspects of scientific explanation and other essays in the philosophy of science, pp. 231-245. New York: Free Press. KIESER, A. AND KUBICEK, H. (1978). Organisationstheorien, Part 1. Stuttgart: Kohlhammer.

${ }^{29}$ WHISLER, T. L. (1970). The impact of computers on organizations. New York: Praeger.

${ }^{30}$ FEDERICO, P. A., BRUN, K. E. AND MCCALLA, D. B. (1985). Management information systems and arganizational hehavior. 2nd edition. New York: Praeger.

${ }^{31}$ EIN-DOR, P. AND SEGEV, E. (1981). A paradigm for management information systems. New York: Praeger.

${ }^{32}$ swanson, E. (1987). Information systems in organization theory: A review. Critical issues in information systems research ( $\mathrm{R} . \mathrm{J}$. BOLAND AND R. A. HIRSCHHEIM EDS), pp. 218-205. Chichester: Wiley. the 'inside' aspects of organizations has been produced by Swanson. ${ }^{32}$ The author presents his findings on impacts on pp. 191-194 of his article. We will give a short list of the main concepts in Swanson's article here because of their importance to the research method we used. For the complete list we refer to Appendix 1.

Main concepts on impacts of IT on internal aspects of organization:
1. Departmentalization.
2. Hierarchy.
3. Span of control
4. Functional differentiation.
5. Delegation of decision-making authority.
6. Evaluation
7. Formalization.
8. Power.
9. Lateral relations.
10. Stability and rigidity.
11. Job routinization.
12. Institutionalization.
13. Competitive advantage.

As a conclusion to this research on the state of the art of impact research 


\section{Swanson writes:}

the effects of information systems upon the organization are as yet poorly understood. Early attempts to explicate these effects appear in retrospect to constitute more of technological forecast, than a theoretical statement within which the role of information systems is consistently articulated. Subsequent work has identified problems with the rationale behind this forecast. However, constructive theoretical progress has been minimal. ${ }^{33}$

We think Swanson is right, there is still a lot of work to be done.

Interesting progress has been made by Lynne Markus. ${ }^{34}$ She points to the lack of differentiation on the variable 'information system', which leads to too general hypotheses. She differentiates between five functional types of information systems. Her choice of a functional typology is important, because she avoids the problem of a technological determinism, and provides a vision of impacts as the result of the activities of providers and users of information systems, within an organizational context. Hence, one of her types need not correspond with only one type of technically realized system. What is most important is that a differentiation in functional types leads to a systematic view of possible impacts. The relation between information systems types and possible impact field are clearly summarized in Table $1 .{ }^{35}$

\section{Research design}

The following assumptions are made in our investigations:

1. Hypotheses can only be meaningfully investigated when compared to several different functional system types.

2. Impacts are under the influence of organizational contexts.

The aim of our investigations is to ground hypotheses on the data available to us from quite unstructured impact explorations by our management school students. As sensitizing concepts we have used some important hypotheses which have been presented by Swanson. ${ }^{36}$ The plausibility of these hypotheses has been tested and data which do not fit one of the hypotheses have been treated separately to explore new hypotheses. This analysis technique is known as 'analytical induction'. ${ }^{37}$

\section{Model}

Three crucial variables are used:

${ }^{33}$ Ibid. p. 196

${ }^{34}$ MARKUS, op. cil., Ref. 2.

${ }^{35} \mathrm{Ibid}$. p. 65

${ }^{36}$ Op. cit., Ref. 32

${ }^{5 /}$ For more information on this technique, the reader is referred to GLASL:R AND

STRAuss, op. cit., Ref. 24.

${ }^{38}$ Op. cit. Ref. 17.

${ }^{39}$ MakKus, op. cit., Ref. 2.

"'Op. cit., Ref. 32.
1. Organizational type, defined in terms of Mintzberg's typology. ${ }^{38}$

2. System type, defined in terms of Markus' typology. ${ }^{39}$

3. Impact, defined as verification or falsification of Swanson's hypotheses. ${ }^{40}$

An important variable which we have identified in our theoretical perspective is the user-designer interaction. We will not study this variable here further because of lack of time and space. We think that a serious study of this variable will need a complete new study. 
Table 1. Relation between information systems types and possible impact fields

\begin{tabular}{|c|c|c|c|}
\hline $\begin{array}{l}\text { System types } \\
\text { and functions }\end{array}$ & Examples & $\begin{array}{l}\text { Key design } \\
\text { features }\end{array}$ & $\begin{array}{l}\text { Related } \\
\text { organizational } \\
\text { features }\end{array}$ \\
\hline $\begin{array}{l}\text { Operational: to } \\
\text { structure }\end{array}$ & $\begin{array}{l}\text { Letter of credit } \\
\text { Computer- } \\
\text { integrated } \\
\text { manufacturing }\end{array}$ & $\begin{array}{l}\text { Work } \\
\text { rationalization } \\
\text { Work } \\
\text { routinization }\end{array}$ & $\begin{array}{l}\text { Work force } \\
\text { composition } \\
\text { Job design } \\
\text { Organizational } \\
\text { structure, work } \\
\text { flow } \\
\text { coordination } \\
\text { Organizational } \\
\text { culture }\end{array}$ \\
\hline $\begin{array}{l}\text { Monitoring and } \\
\text { control: to eval- } \\
\text { uate perfor- } \\
\text { mance and } \\
\text { motivate people }\end{array}$ & $\begin{array}{l}\text { Space } \\
\text { management } \\
\text { Typing produc- } \\
\text { tivity } \\
\text { measurement }\end{array}$ & $\begin{array}{l}\text { Standards } \\
\text { Measures } \\
\text { Evaluation } \\
\text { Feedback } \\
\text { Reward }\end{array}$ & $\begin{array}{l}\text { Job design } \\
\text { Organizational } \\
\text { culture }\end{array}$ \\
\hline $\begin{array}{l}\text { Planning and } \\
\text { decision: to sup- } \\
\text { port intellectual } \\
\text { processes }\end{array}$ & $\begin{array}{l}\text { Planning models } \\
\text { Decision support } \\
\text { systems } \\
\text { Expert systems }\end{array}$ & $\begin{array}{l}\text { Models } \\
\text { Data } \\
\text { manipulation }\end{array}$ & $\begin{array}{l}\text { Work force } \\
\text { composition } \\
\text { Job design } \\
\text { Organizational } \\
\text { structure } \\
\text { Organizational } \\
\text { culture, central- } \\
\text { ization versus } \\
\text { decentralization }\end{array}$ \\
\hline $\begin{array}{l}\text { Communication: } \\
\text { to augment } \\
\text { human } \\
\text { communication }\end{array}$ & $\begin{array}{l}\text { Message systems } \\
\text { Teleconferencing }\end{array}$ & $\begin{array}{l}\text { Communication } \\
\text { procedures } \\
\text { Communication } \\
\text { mediation }\end{array}$ & $\begin{array}{l}\text { Spatial and tem- } \\
\text { poral factors } \\
\text { Communication } \\
\text { channels and } \\
\text { networks }\end{array}$ \\
\hline $\begin{array}{l}\text { Interorgani- } \\
\text { zational: to } \\
\text { facilitate } \\
\text { interorgani- } \\
\text { zational } \\
\text { transactions }\end{array}$ & $\begin{array}{l}\text { Cash manage } \\
\text { ment for corpo- } \\
\text { rate banking } \\
\text { customers } \\
\text { Wholesale } \\
\text { distributors' } \\
\text { order-entry } \\
\text { systems }\end{array}$ & $\begin{array}{l}\text { Procedures for } \\
\text { interorganiza- } \\
\text { tional } \\
\text { transactions } \\
\text { Mediation of } \\
\text { interorgani- } \\
\text { zational } \\
\text { transactions }\end{array}$ & $\begin{array}{l}\text { Relations with } \\
\text { customers or } \\
\text { suppliers } \\
\text { Relations with } \\
\text { competitors }\end{array}$ \\
\hline
\end{tabular}

Note: Of course Markus gives us only a conceptual scheme, and no clear hypotheses. Her scheme, however, gives important structure to a systematical research for discovering and testing hypotheses.

\section{Data generation}

Data are obtained from 11 case studies, intended as exploratory studies in generating insights on impacts of information technology in diverse organizations. On these data secondary analysis is applied, intended to find support or falsification of hypotheses mentioned by Swanson. Scores and contingencies with organizational and system types are listed in a score table (see Appendix 2). Contingencies are analysed. Important data which do not fit into Swanson's hypotheses are treated separately. 


\section{Results from empirical research}

Span of control

Robey's hypothesis pointed to the probability of substitution of impersonal control for direct supervision; and widening of span of control. ${ }^{4}$ However, a relationship between impersonal control and widening of span can be imagined; we have no evidence for this, and in none of our cases was widening of span of control and impersonal control found together.

Substitution of impersonal control for direct supervision was found in three cases. All were bureaucracies, and used monitoring and control systems. In a hard- and software development bureau, the system increased efficiency, and on-time work flow. In an accounting business, an increase in monitoring and control was evident, which did not affect employees' perception of their job discretion. No dissatisfactions, therefore, were signalled. At an insurance company the monitoring and control system increased employees' opportunities for self-control, and made a small bit of performance payment possible. Employees were satisfied with both!

Increase in span of control was found in a service bureau of a computer multinational, which could be positioned as somewhere in between a professional bureaucracy and adhocracy. At another big computer firm increase of span of control was an aim of automation. However, the objective was not met, because managers' and employers' attitude did not change.

\section{Differentiation}

Pfeffer's thesis ${ }^{42}$ which pointed to the probability of a decrease in differentiation was clearly sustained in eight cases, with some differences in organization and systems type.

In a department of a trucking factory, the production planner took over the johs of foreman and procurement manager. This was made possible because of a well functioning planning and decision system. An administration system gave druggists the possibility for bridging the gap which traditionally existed between the office and shop work. The same kind of impact was found in a small bank, where back and front office activities became more integrated. In a high tech firm the administrative automation caused the administrative department to attract jobs in the field of coordination and planning (higher up the support staff, Mintzberg ${ }^{43}$ ). Well functioning word processing and archiving gave the operating core in a ministry the opportunity of taking over some secretaries' tasks very efficiently. Of course secretaries were not made redundant. The same impact occured in a big computer firm, where managers took over some secretaries' functions. At a newspaper, editors took over a lot of traditional printer's functions. A computer service bureau became less deconcentrated, which was possible now because of faster and better communication technology.

\section{Centralized control}

$51^{44}$

${ }^{41}$ Ibid.

${ }^{43}$ Op. cit., Ref. 17.

${ }^{44}$ Refers to hypothesis number in Appendices 1 and 2 .
Druggists relied less on intuition in their decisions, and more on data and their analysis. Accountants felt a greater increase in analytical possibilities by working with computer models. Also, in other cases some support for this hypothesis was found. If looked at closely, this 
hypothesis falsification will be difficult. The hypothesis refers especially to personal computer use, supporting employees in individual work settings.

\section{3}

Because of more rapid and accurate performance feedback, opportunities for decentralization and deformalization can be enlarged. This thesis was supported in a high-tech firm and an insurance company, where more possibilities for self control were developed for administrative personnel and insurance sales people. Again, like in thesis 51, IT had an impact on people with quite independent work.

In contrast, two banks, organized as very big mechanized bureaucracies with strongly centralized information management, showed more centralization and more formalization. In a divisionalized bank with decentralized information management the exact opposite of these bank findings was found!

\section{Delegation}

61

Whisler's thesis of decision centralization ${ }^{45}$ was not supported, and falsified in the case of the trucking factory. In the last case, employees on the work floor received more opportunities for job discretion (self-planning).

\section{Evaluation}

72

Information systems support the creation of outcome measures and their comparison and summarization. In the trucking plant performance indicators led to a raising of a department's status, because now information became available indicating that this department was not to blame for a lot of complaints about the production process. In the insurance company, data became available on which performance payment could be based.

73

In the druggist's branch, statistics and written reports were generated for the first time, which increased the objective rationality of decisionmaking by druggists remarkably.

\section{Formalization}

\section{2}

Instead of facilitating a more organic style of organization, and common referents between people, the communication system at a high-tech factory led to more formalized communications, and more ethnocentrism between departments. In a mechanized bureaucratic bank, strong formalization was also found.

83

The thesis of more formalization of communication is consistent with the last mentioned case. At a university and a ministry (use of electronic mail), easier retrieval and communication of formalized data was found. At the computer service bureau, more formalized communication and decision changed the adhocracy organization type into a bureaucracy. 
92

In a high-tech factory, the department of production control increased in importance because the computer equipped it with facilities to carry out more quality control. When the service bureau of the computer company installed the computer at their own office, they became much more autonomous. At the newspaper, editors had a strong say in what kind of system should be established. In the automation process, printers were quite anxious for their jobs and opposed it. The editors' ideas could not be stopped by them.

\section{Lateral relations}

101

In the druggists' study, we found an increase of cooperation among druggists in their efforts to create a useful information system, thus becoming less dependent on their suppliers. At the university, easier retrieval of student information supported lateral relations between student administration and bureau of education. Office information systems were created explicitly at the ministry for facilitating lateral relations. At the university and the ministry, a lot of political motives made lateral relations extremely difficult to create. At a multinational computer firm, electronic mail facilitated lateral relations, especially because time differences could now be more easily managed.

\section{Stability and rigidity}

114

Office information systems at the ministry have some potential for creating more market-like organizations and adhocracy. We have only weak evidence for this; and certainly new ways of coordination have yet to be established.

At a bank, more dependence on a very rigid system was signalled especially with respect to payments to customers. Money could not be taken from the safe until all necessary data were entered in the computer system.

\section{Job routinization}

122

In an accounting company information technology at the administrative department (mechanized bureaucracy) by use of an operational system led to strong job routinization. At the accountanting department (professional bureaucracy) we found that the use of planning and decision systems increased work satisfaction, probably because of more job variation and diminishing of routine work. In a high-tech factory, the operational system for the administrative department led to routinization and dissatisfactions.

At one big bank, the content of the operators' function was routinized, and the supervisory function was enlarged (especially computer management tasks).

123

If we view accountants as performing (external) middle management functions, a diminishing of repetitious work for these jobs is found, and they can spend more time on communication, interpretation and 
counselling. The same was found for the staff bureau of the truck factory, and the work of the manager druggist's shop.

124

The administrative system of the credit administration department in a high-tech factory showed clear evidence for the polarization thesis. Degradation of position of data entry personnel, and strong promotion opportunities for system experts were visible. Druggists showed a need for higher qualifications and education; the engineering bureau at a high-tech factory showed a need for higher education of administrative personnel. Secretaries al a high-tech firm with more computer knowledge increased their importance. In a big computer firm, a strong polarization appeared between secretaries who got a very routine telex function, and those whose job changed into a more sophisticated and higher status information manager-like job. Polarization was also observed at the two big banks.

\section{Competitiveness}

141

Efficiency was increased in the druggists' shops with lower inventory costs (more control) and better planning, because the system made statistics available. At the high-tech factory information systems made better efficiency possible because there is more insight in already existing modules of their very complicated information intensive products. At a wholesaler for technical products, competitiveness increased because of:

1. Faster deliveries, although opportunities for low cost central inventory were still available.

2. Fast communication between retailer and central inventory.

At the accounting firm, reliability seemed to be an extremely important quality measure, which strongly increased by use of administrative systems. Data interchange with clients was also available. Communications with several agencies of the firm around the world was attempted. This last opportunity is extremely important for serving multinational firms, and is, therefore, an important factor in obtaining these huge clients. However, standardization of equipment seems to be difficult to achieve.

At the insurance company, more self control of sales people increased the effectiveness of their selling campaigns. More control of credits made a strong lowering of rent costs possible in the high-tech factory. At a high-tech firm, CAD/CAM led to professionals being able to make better judgements on the quality of their products. They also could more easily offer clients several alternatives with different prices. A monitoring and control system at the same firm extensively lowered the costs and time problems of project work.

All the banks used the improvement of service to the client as the most important argument for automation. However, no factual evidence at the banks suggested increased competitiveness! Most probably the argument of client service is used as a legitimation of automation policy to opponents like labour unions.

\section{Observations not fitting one of the hypotheses: Job satisfaction}

1. At a high tech firm: less tedious administrative work of workers on 
the workfloor, which was always regarded as very unsatisfactory; task shifts (and discussions on this) between the final control department and manufacturing bureau caused serious conflicts between the departments. Especially, final control was very frustrated because they lost an important task.

In the same firm in the administration department: more routinization of jobs led to more job dissatisfaction.

2. At the university: less irritation, more job satisfaction, because less went wrong; large turnover of employees during implementation, which points to the probability of great social stress during implementation (we do not have clear evidence on this); faster/easier retrieval was felt to be very satisfactory.

3. At the components engineering bureau of a high-tech factory: more job satisfaction; employees were very closely participating in the system development process.

4. At the ministry: job satisfaction increased by use of good word processing and archiving.

5. At the accounting firm: at the administrative department (mechanized bureaucracy) routinization/rationalization increased work dissatisfaction; the accountants (professional bureaucracy) noticed an increased satisfaction (better models were available, etc).

6. Insurance company: some performance payment now was possible, which seemed to be very stimulating.

7. At a high-tech firm: implementation without participation of employees led to strong resistance.

\section{Conclusions from the research findings}

Systems very often have been shown to be useful in realizing more centralization and impersonal control. Adhocracy elements in organizations were often reduced by using operational and monitoring and control systems. Professionals seemed to be very pleased with operational information systems, because they eliminated tedious jobs and organizational bottle-necks and gave them opportunities to do their work in a better way. They enjoyed their work more. This is very different from the experiences of non-professional workers, who met with more routinization, rigidity and job dissatisfactions.

Competitiveness was very often increased because of great cost savings and better service to clients. Communication and interorganizational systems seemed to be very important in this respect.

Of course these findings give some overview of impacts of information technology, but may never be interpreted as causal natural laws. The reason for this is not the non-randomness of the sample, but because the signalled impacts are always the result of the way systems are implemented in organizations. This implementation process is a policy process in which several choices can be made which refute our findings. The reader is referred to Markus' ideas about this implementation process, to understand more fully what we mean here.

\section{Issues for further research and system development practice}

The results of our research have shown that information technology is 
often very useful in making organizations more competitive; however, some problems exist with this conclusion. Further research on this is necessary.

One point is that efficiency and effectiveness of organization (including its competitiveness) were very difficult to measure in a precise way. Especially in non-business organizations (like government) these criteria seem to be of almost no use.

Another problem is the unsystematic nature of our sampling method, which gives fewer opportunities for systematic evidence generation.

A third problem is the absence of systematic research on the interaction process between designers and users in an organizational context. Lack of time and space forced us to disregard this aspect in our analysis.

A fourth point is needed for more system development practice, with the clear intention of also making jobs more attractive, or reducing the risk of making jobs less attractive. This aspect is often completely disregarded in present information science courses, and can cause serious problems for our future society.

A final problem that will exist is also the great opportunities for information technology of reducing labour needs. Serious research has to investigate how to avoid the great social and economical problems that can result from increasing unemployment in this way. Maybe the Hobbesian problems of dysfunctions for society of egoist (organizational) behaviour by dumping people in unemployment has to be reconsidered by Leviathan.

\section{Appendix 1. Full list of Swanson's hypotheses}

\section{E.1. Departmentalization}

$\therefore$ information technology will have substantial effects upon the pattern of departmentation in the company. The main effect should be the aggregation of previously separate information-processing activities into the computer center'. ${ }^{46}$

(In a study of manufacturing concerns) 'Neither is there any evidence that automation of plant functions by on-site computers leads to the consolidation of departments . . and a reduction in their number' ${ }^{47}$

\section{E.2. Hierarchy}

'When a technology that displaces people is adopted, if that displacement takes place fast enough and in sufficient degree to offset organizational growth, a decrease in the number of levels in the organization should result'. ${ }^{48}$

'Contrary to Whisler's assumption, ... computer use tends to increase rather than decrease the number of administrative levels in the plant hierarchy. The probable reason is that a computer system serves as an impersonal mechanism of control, which makes it less disadvantageous for top management to be separated by the workflow by many hierarchical levels'. ${ }^{49}$

${ }^{46}$ Op. cit., Ref. 29, p. 48.

${ }^{47}$ BLAU et al. (1976). p 32, op. cit., Ref. 32.

${ }^{48}$ Op. cit, Ref. 29 , p. 47. See also I.EAvitT AND WHISLER (1958), op. cit., Ref. 32.

${ }^{49}$ Op. cit., Ref. 47, p. 32.

\section{E.3. Span of control}

'It has been found . . . that the average span of control in organizations is related to the degree of centralization of control ... Control is 
${ }^{50}$ Op. cit., Ref. 29, p. 46 , op. cit., Ref. 32

${ }^{51}$ ROBEY (1981). pp. 684-685.

${ }^{9}$ PFEFFER AND LEBLEBICI (1977). p. 247 op. cit., Ref. 32. See also Refs 29 and 51.

${ }^{5}$ Op. cit., Ref. 52, pp. 247-248.

${ }^{54}$ PFEFFER (1978). p. 75, See also STABFLL (1976), op. cit., Ref. 32.

"LEAVITT AND WHISLER, op. cit., Ref. 48 , p. 296. See also Ref. 29.

PFEFFER, op. cil., Ref. 54, p. 70.

57 p. cit., Ref. 52 , p. 248 .

${ }^{58}$ Op. cit., Ref. 29 , p. 69.

${ }^{5 \%}$ Op. cit., Ref. 52, p. 248

${ }^{60}$ Op. cit., Ref. 51, p. 681 . See also robiy

(1977), op. cit., Ref. 32

61 PFEFFER, op. cit., Ref. 54, p. 81.

${ }^{62}$ Ibid. p. 76

${ }^{63}$ Op. cit., Ref. 52, p. 248 increasingly centralized as a consequence of computer use. Therefore, a reduction in the average span of control . . should take place'. ${ }^{50}$

'Automation permits structural elaboration because impersonal control can be substituted for direct supervision, and the span of control can be widened. ${ }^{51}$

\section{E.4. Functional differentiation}

'. . . through enhancing the managers" own information processing and handling capabilities, it permits the manager to control and coordinate more complex, differentiated organizations'. ${ }^{52}$

'We would hypothesize ... that information technology would be positively associated with both vertical and horizontal differentiation in organizations: ${ }^{5.3}$

$\because$. . by generally increasing the information processing capacity of positions in the organization, the implementation of information technology may make less division of labor and task specialization necessary in the organization'. ${ }^{54}$

'By permitting more information to be organized more simply and processed more rapidly it will, in effect, extend the thinking range of individuals'. ${ }^{55}$

'Information technology, particularly computer technology, enhances the information processing capability of persons, leading to possible alterations in the systems of control and governance'. ${ }^{56}$

'We hypothesize that information technology, through its provision of more rapid and accurate performance feedback, would be associated both with more decentralization and less formalization'. 57

\section{E.6. Delegation of decision-making authority}

'Specifically, what will tend to occur is a relocation of human choicemaking and goalsetting in the newly established decision systems to higher organizational levels than was true in precomputer systems'. ${ }^{5}$

'Using outcome measures, less emphasis would be given to process (rules of procedure), and more decision-making authority could be delegated to subordinates. .99

'. . what appears to be greater decentralization may simply entail the delegation of more routine decisions whose outcomes are more closely controlled' ${ }^{6(t)}$

\section{E.7. Evaluation}

'Those things that are measured tend to be used, particularly if they are easy to process, and those that are not measured are not used in the evaluation process' ${ }^{\prime \prime}$

'It is difficult to develop forms of computer systems that assess the process by which a job is done. Conversely, outcome measures can be implemented using information technology, and indeed, information technology facilitates the collection of a multitude of outcome measures, and their comparison and summarization'. ${ }^{2}$

'It is hypothesized that information technology is associated positively with the use of formal written reports and detailed statistics, and is inversely related to the use of oral evaluations of performance'. 6.3

\section{E.8. Formalization}

'Information technology enhances the possibility of monitoring com- 
pliance with procedures and rules ... At the same time, however, because of the ability to obtain feedback on organizational performance, the implementation of rules and procedures is less necessary". ${ }^{64}$

'By allowing easy and timely linking to a broad set of individuals with common referent bases, terminal-oriented communications seem to facilitate an organic style of organization; and if the task/environment so demands it facilitates a good fit'. ${ }^{65}$

'. . post-industrial technologies will cause decision processes to be more formalized. . . advanced communication devices will increase the accessibility of any source of information, formal or informal. Since the attractiveness of informal sources is largely a function of their ready accessibility, the proportion of information that is formally acquired and processed will increase'. 66

\section{E.9. Power}

'While there are reasons to expect a CIS to centralize organizational control, instances of no change outweigh the incidence of change in this research ... Where CIS does not produce changes in structure, it reinforces existing structure' ${ }^{67}$

'The computer, because of its importance in assessing and controlling organizational performance, is likely to increase the centrality of any subunit where it is housed' 68

. . . control is not a simple zero-sum relationship and . . various groups may experience enhanced power and decision-making opportunities after computerization'. ${ }^{69}$

$\because \ldots$ in terms of effective organizational control or in terms of the distribution of influence within the organization, the most likely outcome is an increased concentration of power'. ${ }^{70}$

\section{E.10. Lateral relations}

'Common computer-based techniques ... are frequently used to coordinate lateral activities in organizations, ${ }^{71}$

\section{E.11. Stability and rigidity}

'It is more difficult to change computerized decisions systems, because it

${ }^{64}$ PFEFFER op. cit., Ref. 54, p. 77 . See also Ref. 52.

${ }^{65}$ MCKENNEY (1985). p. 17 , op. cit., Ref. 32.

${ }^{66}$ HUBER (1984). p. 936.

${ }^{67}$ Op. cit., Ref. 51 , p. 684 . See also KLING (1980). KLING AND SCACCH (1980) and DANZIGER et al. (1982), op. cit., Ref. 32.

${ }_{6}^{8}$ PFEFFER, op. cit., Ref. 54, pp. 82-83. See also BARIFF AND GALBRAITH (1978), op. cit., Ref. 32.

${ }^{69}$ ATTEWELL AND RULE (1984), p. 1189 . See also BJORN-ANDERSEN (1977), MARKUS (1983), op. cit., Ref. 32. and markus, op. cit., Ref. 2.

${ }^{7}$ PFFFFER, op. cit., Ref. 54 , p. 73.

${ }^{7} \mathrm{Op}$. cit., Ref. 51, p. 648 . See also MALONE AND SMITH (1984)

${ }^{72}$ Op. cit., Ref. 29, p. 89.

${ }^{73}$ A.RGYRIS (1977). p. 117, op. cit., Ref. 32. ${ }^{74}$ HEDBERG AND JONSSON (1978). p. 47. See also STARBUCK (1975), HEDBERG et al. (1976), and DERY (1981), op. cit., Ref. 32.

${ }^{75}$ Op. cit., Ref. 71, p. 26. is more expensive. Also, change is less likely to occur, because fewer people have a real grasp of the logic involved in these systems'. ${ }^{72}$

(From MIS) . . 'organizations seem to have the capacity to learn primarily those lessons that are self-sealing because they maintain the status quo..$^{73}$

'They filter away conflicts, ambiguities, overlaps, uncertainty, etc. and suppress many relevant change signals and kill initiatives to act on early warnings' ${ }^{74}$

'(A) possibility is that the coordination mechanisms actually used inside large firms will come to resemble the structure of a decentralized market more than that of a rigid hierarchy. For example, the widespread use of electronic mail, computer conferencing, and electronic bulletin boards can facilitate what some observers have called "adhocracies" that is, rapidly changing organizations with many shifting projcct teams composed of people with different skills and knowledge'. ${ }^{75}$

\section{E.12. Job routinization}

'One major effect of information technology is likely to be intensive 
${ }^{76}$ Op. cit., Ref. 48, p. 270.

${ }_{73}^{77}$ Ibid., p. 141

${ }^{78}$ Op. cit., Ref. 29, p. 132

${ }^{70)}$ HUNT ANI NEWEII. (1971), p. 281, op cit., Ref. 32.

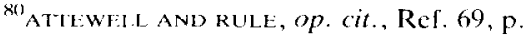
1187.

${ }^{81}$ MEYER AND ROWAN (1977), p. 344. quOted in PFEFFER (1982), p. 247, op. cit. Ref. 32.

Y2PORTER AND MIILAR (1985). p. 156, op cit., Ref. 32 programming of many jobs now held by middle managers and the concomitant "deprogramming" of others'. ${ }^{76}$

'On balance, clerical jobs have become more routinized ${ }^{77}$ 'As the wave of change moves on, the pattern of change in supervisory jobs should eventually approximate that at the clerical level'. ${ }^{78}$

'With the advent of computers, middle managers spent more time on such function as communication, interpretation, and counsel . . Repetitious, routine aspects of their jobs disappeared'. ${ }^{79}$

'Surveys of workers' perceptions of new technology generally contradict the deskilling/job degradation thesis'.

\section{E.13. Institutionalization}

... technologies are institutionalized and become myths binding on organizations. Technical procedures of production, accounting, personnel selection, or data processing become taken-for-granted means to accomplish organizational ends. Quite apart from their possible efficiency, such institutionalized techniques establish an organization as appropriate, rational, and modern. Their use displays responsibility and avoids claims of negligence'. ${ }^{81}$

\section{E.14. Competitive advantage}

'In any company, information technology has a powerful effect on competitive advantage in either cost or differentiation'. ${ }^{2}$

\section{Appendix 2}

List of scores. Case unit numbers are put behind the point

\begin{tabular}{|c|c|c|c|}
\hline Organization type & System type & Hypothesis & Score \\
\hline $\begin{array}{l}1=\text { Simple structure } \\
2=\text { Mechanized bureau } \\
3=\text { Professional } \\
4=\text { Divisionalized } \\
5=\text { Adhocracy }\end{array}$ & $\begin{array}{l}1=\text { Operational } \\
2=\text { Monitoring/control } \\
3=\text { Planning/decision } \\
4=\text { Communication } \\
5=\text { Interorganization }\end{array}$ & $\begin{array}{l}\text { Correspon- } \\
\text { ding with } \\
\text { Swanson's } \\
\text { order; only } \\
\text { hypotheses } \\
\text { with scores } \\
\text { are taken in } \\
\text { this list }\end{array}$ & $\begin{array}{l}+=\text { Verified } \\
-=\text { Falsified }\end{array}$ \\
\hline $2.3 ; 2 / 3.8 ; 2.9$ & $2.3 ; 2.8 ; 2.9$ & 32 & $3 ; 8 ; 9$ \\
\hline $2.1 ; 1.2 ; 3.6 ; 2.7$ & $3.1 ; 1.2 ; 1.6 ; 1.7$ & 43 & $1 ; 2 ; 6 ; 7$ \\
\hline $1.2 ; 3.8$ & $3.2 ; 3.8$ & 51 & $2 ; 8$ \\
\hline $3.6 ; 2.9$ & $1.6 ; 2.9$ & 53 & $6 ; 9$ \\
\hline 2.1 & 1.1 & 61 & 1 \\
\hline $2.1 ; 2.9$ & $1.1 ; 2.9$ & 72 & $1 ; 9$ \\
\hline 1.2 & 1.2 & 73 & 2 \\
\hline 2.3 & 4.3 & 82 & 3 \\
\hline $2.3 ; 2.5 ; 2.7$ & $4.3 ; 1.5 ; 1.7 ; 4.7$ & 83 & $3 ; 5 ; 7$ \\
\hline 2.3 & 2.3 & 92 & 3 \\
\hline $2.1 ; 2.5 ; 2.7$ & $3.1 ; 1.5 ; 4.7$ & 101 & $1 ; 5 ; 7$ \\
\hline
\end{tabular}




\section{Appendix 2 Continued}

List of scores. Case unit numbers are put behind the point

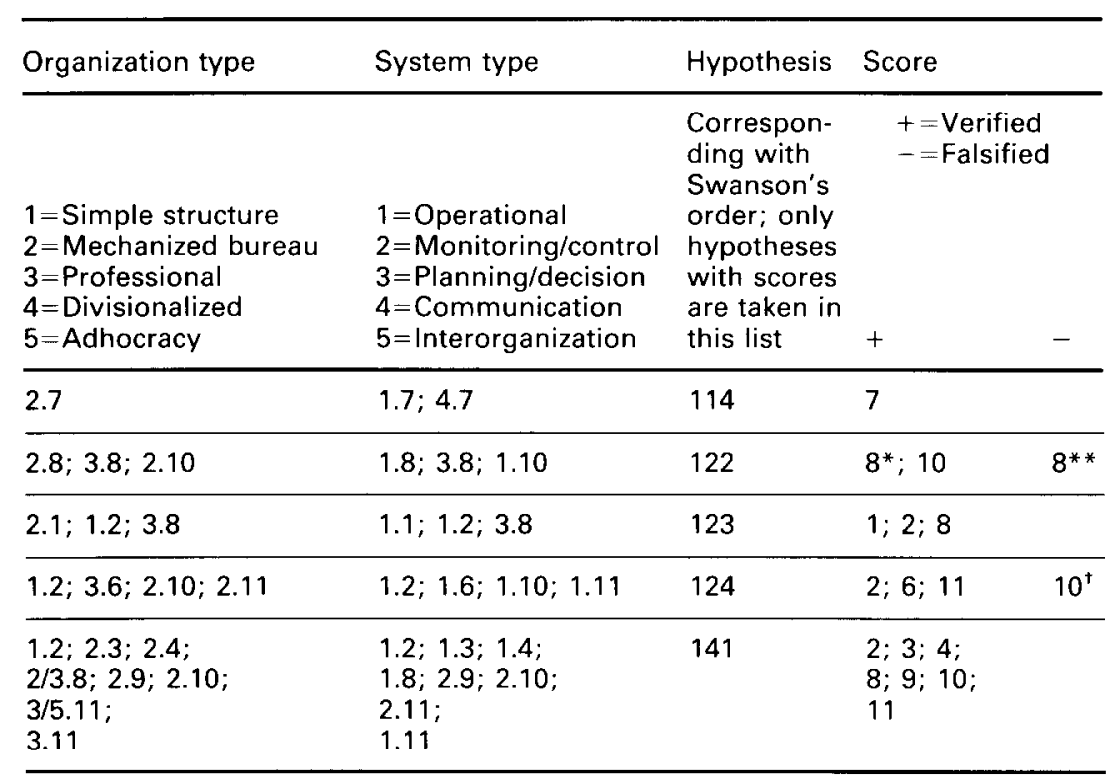

*At organization type 2 and system type 1

**At organization type 3 and system type 3

${ }^{\dagger}$ Indication of polarization thesis. 